posium (pp. 107-117). New York: Appleton-Century-Crofts.

Hoffman, H. S., \& Fleshler, M. (1962). The course of emotionality in the development of avoidance. Journal of Experimental Psychology, 64, 288-294.

Horner, J. L., Longo, N., \& Bitterman, M. E. (1961). A shuttlebox for the fish and a control circuit of general applicability. American Journal of Psychology, 74, 114-120.

Hoshino, Y. (1988). Reflexivity of avoidance behavior in the crayfish. Annual of Animal Psychology, 38, 107-120. (In Japanese)

Hunter, W. S. (1935). Conditioning and extinction in the rat. British Journal of Psychology, 26, 135-148.

Kamin, L. J. (1956). The effects of termination of the CS and avoidance of the US on avoidance learning. Journal of Comparative and Physiological Psychology, 49, 420-424.

Klinman, C. S., \& Bitterman, M. E. (1963). Classical conditioning in the fish: The CS-US interval. Journal of Comparative and Physiological Psychology, 56, 578-583.

Leschova, T. S., \& Zhuikov, A. Y. (1989). Fish learning: Ecological and applied aspects. Moscow: Nauka. (In Russian)

Levis, D. J. (1989). The case for a return to a two-factor theory of avoidance: The failure of non-fear interpretations. In S. B. Klein \& R. B. Mowrer (Eds.), Contemporary theories of learning: Pavlovian conditioning and the status of traditional learning theory (pp. 227-275). Hillsdale, NJ: Erlbaum.

Logan, F. A. (1951). A comparison of avoidance and nonavoidance eyelid conditioning. Journal of Experimental Psychology, 42, 390-393.

Mackintosh, N. J. (1983). Conditioning and associative learning. New York: Oxford University Press.

Mowrer, O. H. (1947). On the dual nature of learning-a reinterpretation of "conditioning" and "problem-solving." Harvard Educational Review, 17, 102-148.

Mowrer, O. H. (1956). Two-factor learning theory reconsidered, with special reference to secondary reinforcement and the concept of habit. Psychological Review, 63, 114-128.

Mowrer, O. H. (1960). Learning theory and behavior. New York: Wiley.

Moyer, K. E., \& Korn, J. H. (1964). Effect of UCS intensity on the acquisition and extinction of an avoidance response. Journal of Experimental Psychology, 67, 352-359.

Overmier, J. B., \& Hollis, K. L. (1990). Fish in the think tank: Learning, memory, and integrated behavior. In R. P. Kesner \& D. S. Olton (Eds.), Neurobiology of cognition (pp. 205-236). Hillsdale, NJ: Erlbaum.
Overmier, J. B., \& Starkman, N. (1974). Transfer of control of avoidance behavior in normal and telencephalon ablated goldfish (Carassius auratus). Physiology and Behavior, 12, 605-608.

Schmajuk, N. A. (in press). The frightening complexity of avoidance: An adaptive network approach. In C. D. L. Wynne \& J. E. R. Staddon (Eds.), Models of action. Hillsdale, NJ: Erlbaum.

Scobie, S. R., \& Fallon, D. (1974). Operant and Pavlovian control of a defensive shuttle response in goldfish (Carassius auratus). Journal of Comparative and Physiological Psychology, 86, 858866.

Shishimi, A. (1985). Latent inhibition experiments with goldfish (Carassius auratus). Journal of Comparative Psychology, 99, 316-327.

Solomon, R. L., \& Wynne, L. C. (1953). Traumatic avoidance learning: Acquisition in normal dogs. Psychological Monographs, 67, No. 4.

Theios, J. (1963). Simple conditioning as two-stage all-or-none learning. Psychological Review, 70, 403-417.

Theios, J., Lynch, A. D., \& Lowe, W. F., Jr. (1966). Differential effects of shock intensity on one-way and shuttle avoidance conditioning. Journal of Experimental Psychology, 72, 294-299.

Wahlsten, D. L., \& Cole, M. (1965). Classical and avoidance training of leg flexion in the dog. In W. Prokasy (Ed.), Classical conditioning: A symposium (pp. 379-408). New York: AppletonCentury-Crofts.

Warner, L. H. (1932). The association span of the white rat. Journal of Genetic Psychology, 41, 57-90.

Wilson, G. T. (1973). Counterconditioning versus forced exposure in extinction of avoidance responding in rats. Journal of Comparative and Physiological Psychology, 82, 105-114.

Wodinsky, J., Behrend, E. R., \& Bitterman, M. E. (1962). Avoidance conditioning in two species of fish. Animal Behaviour, 10, 76-78.

Woodard, W. T., \& Bitterman, M. E. (1971). Classical conditioning of goldfish in the shuttlebox. Behavior Research Methods and Instrumentation, 3, 193-194.

Woodard, W. T., \& Bitterman, M. E. (1973). Pavlovian analysis of avoidance conditioning in the goldfish (Carassius auratus). Journal of Comparative and Physiological Psychology, 82, 123-129.

Received January 1, 1993 Revision received July 15, 1993 Accepted July 15, 1993

\title{
Correction to Author Index for Volume 19
}

The article "Temporal Encoding as a Determinant of Blocking," by Robert C. Barnet, Nicholas J. Grahame, and Ralph R. Miller (Journal of Experimental Psychology: Animal Behavior Processes, 1993, Vol. 19, No. 4, pp. 327-341) was inadvertently omitted from the author index to the volume. 